\title{
Many refugees still denied care despite ruling
}

A ccess to health care for many refugees remains severely disrupted as federal efforts to cut their health care coverage continue. According to results of several studies presented at the North American Refugee Health Conference June 4 in Toronto, refugees legally entitled to federally funded health care are now being turned away from scores of clinics in Montréal and Toronto.

The consequences for refugees are egregious, illegal and risk-laden for the Canadian public, said Dr. Meb Rashid, co-founder of Canadian Doctors for Refugee Care, the physicians' group that successfully litigated against federal cuts implemented in 2012.

"The federal government is now in court fighting to take coverage away from children and pregnant women," Rashid said. "We're hearing stories of people - including pregnant women - being turned away from hospitals because the hospitals don't understand the coverage. We're seeing massive confusion stemming from the government's legal manoeuvres."

The manoeuvres in question, Rashid explained, are part of Ottawa's reaction to a July 2014 Federal Court of Canada ruling that a federal Cabinet order in April of 2012 (a ruling that denied health care to failed refugee claimants, as well as to claimants from countries Ottawa deems to be safe), was illegal and "of no force."

Ordered by the Federal Court to fully restore refugee health coverage by November 2014, the Minister of Citizenship and Immigration, Chris Alexander, instead adopted legal tactics aimed at continuing to dismantle it, says Rashid. The government launched a legal appeal of the decision. It devised a complicated new refugee health care program that, according to Rashid, seems almost intentionally aimed at sowing sufficient confusion to ensure coverage is denied by many health care providers. And in a legal maneuver first revealed in the CMAJ in February

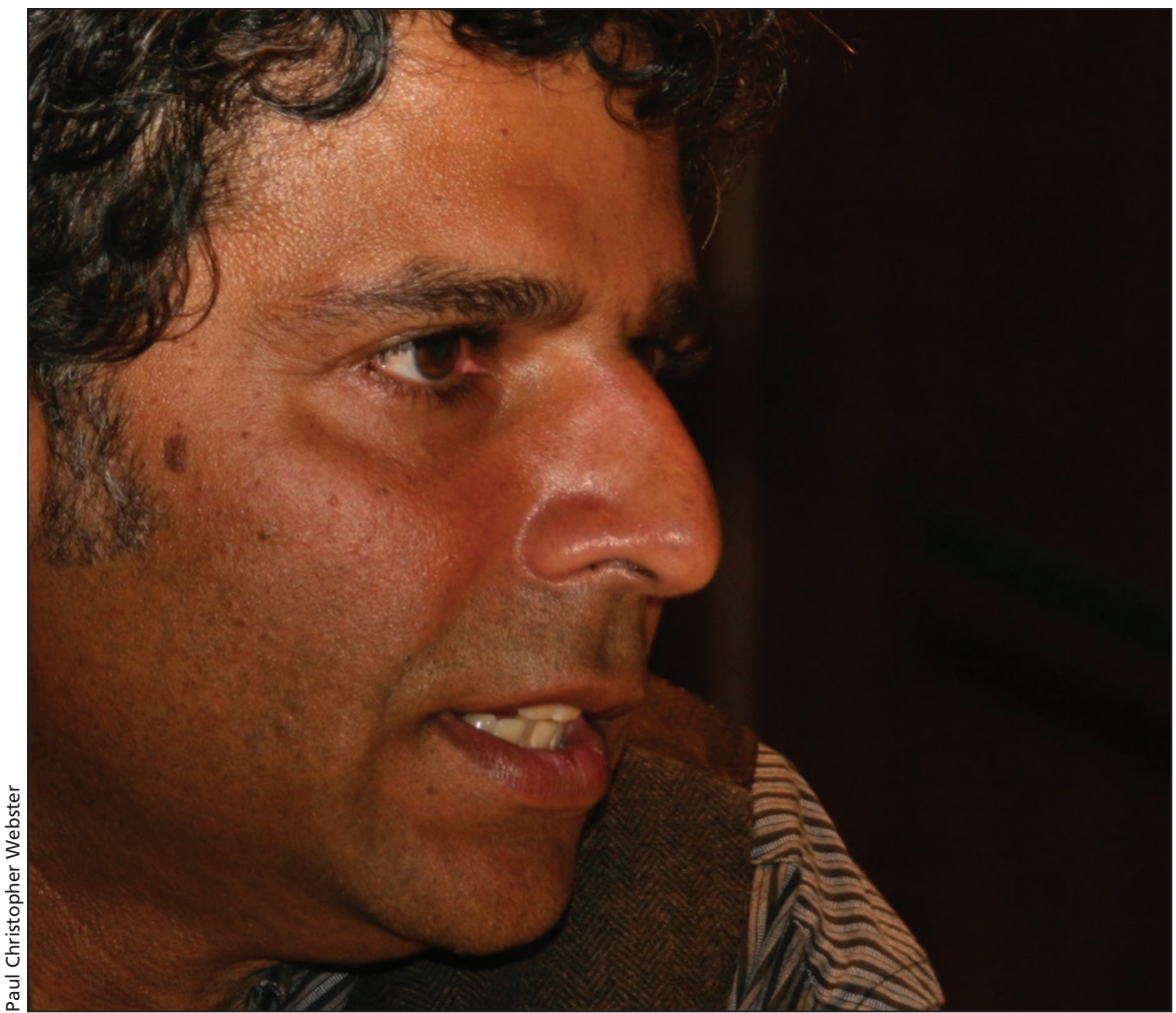

The federal government is not following the spirit of the law in terms of refugee health care, contends Dr. Meb Rashid, co-founder of Canadian Doctors for Refugee Care.

2015, the federal Cabinet quietly revoked the entire legal basis for federal funding of refugee health care first established in 1957.

"Did the government comply with the letter of the federal court judgment? Maybe," Rashid reflected at a conference session during which almost 30 physicians expressed confusion over federal policies. "Did the government comply with the spirit of it? Definitely not."

A representative from the federal Department of Citizenship and Immigration at the session confirmed she was "taking notes," but declined to clarify the federal policies. In an earlier presentation at the conference, Dr. Sylvain Bertrand, senior director of health operations for Citizenship and Immigration Canada, acknowledged serious problems with federal management of refugee health care. "We're not always speaking the same language when we are speaking with our colleagues."
Evidence from several studies presented at the conference affirmed Rashid's contention that federal policies continue to severely diminish refugee access to health care. This, at a time when Ottawa is aligning refugee policies with its military strategies by sharply increasing the number of refugees from war-torn Iraq and Syria. Many of these people are suffering from acute mental and physical conditions, said psychologist Ghayda Hassan of the Université du Québec à Montréal.

Preliminary data from a federally funded study of refugee health care in 14 hospitals in Montréal and Toronto, covering five years before and two years after the 2012 federal cuts, shows a $50 \%$ decrease in the number of hospitalizations, emergency department visits and outpatient visits among federally insured refugees in the first year after the cuts. The study found that large costs stemming from unpaid 
federal claims were absorbed by hospitals in the two years after the 2012 cuts.

These findings, said co-investigator Janet Cleveland, a McGill Universitybased lawyer and psychologist, confirm that the 2012 cuts have had negative consequences for refugees who are legally entitled to federal coverage. Confusion about refugee claimants' health care coverage is pervasive and is aggravated by multiple federal policy shifts, she added. Many refugee claimants are refused care or charged fees, even when they are entitled to free care. Cleveland explained that many doctors who provide services to refugees do not make payment claims because the combined federal and provincial billing systems are onerous and poorly understood.

According to a telephone survey of Montréal clinics conducted last year, Cleveland added, about one-third of clinics accept federally insured refugee patients free of charge, and about one in five clinics charge fees to refugee patients with valid federal insurance.

Results from an audit of Toronto clinics conducted by Dr. Alexander
Caudarella were also presented at the conference. It found that after the 2012 cuts, only $29 \%$ of the 89 walk-in and after-hours clinics fully accepted refugees, even though these people are entitled to care.

"Refugees with valid [federal health insurance] papers do not have appropriate access to the majority of walk-in clinics in the Greater Toronto Area following the 2012 federal cuts," said Caudarella. - Paul Christopher Webster, Toronto

CMAJ 2015. DOI:10.1503/cmaj.109-5093 